\title{
The ecological role of overwintering fish in the food web of the Culbin Sands lagoon ecosystem, NE Scotland: Identifying major trophic links and testing effects of the fish Pomatoschistus microps (Pallas) on benthic invertebrates
}

\author{
VANDA MARIYAM MENDONÇA ${ }^{1,2}$, DAVID RAFFAELLI ${ }^{3}$, PETER BOYLE $^{4}$ and \\ CHAS EMES ${ }^{5}$ \\ ${ }^{1}$ Marine Science and Fisheries Centre, Ministry of Fisheries, P.O. Box 467, Muscat 113, Oman. \\ E-mail: drvandamendonca@yahoo.com \\ ${ }^{2}$ Centre of Marine Sciences (CCMAR) / Centre of Marine and Environmental Research (CIMAR), University of Algarve, \\ Gambelas 8000 Faro, Portugal. \\ ${ }^{3}$ Department of Environment, University of York, YO 105DD, UK \\ ${ }^{4}$ Department of Zoology, University of Aberdeen, AB 24 2TZ, UK. \\ ${ }^{5}$ Biodiversity and Conservation Field Station, University of Aberdeen, Newburgh, AB 41 OAA, UK.
}

SUMMARY: The Culbin Sands lagoon ecosystem in NE Scotland was studied during a three-year period (1994-1996) to identify the major trophic links from benthic invertebrates to epibenthic predators, and to assess impacts of overwintering fish on their prey communities. Every 2-4 weeks, samples of mobile fauna were collected to study their diets. The major trophic links identified between benthic invertebrates and epibenthic predators were from benthic invertebrates to the shrimp Crangon crangon, and to the common goby Pomatoschistus microps and the plaice Pleuronectes platessa. The energy flow from benthic invertebrates to overwintering fish was estimated at $133 \mathrm{~kJ} \mathrm{~m}^{-2} \mathrm{yr}^{-1}$. A flow of $10 \mathrm{~kJ} \mathrm{~m}^{-2} \mathrm{yr}^{-1} \mathrm{was}_{\text {also observed }}$ from eggs and larval stages of the overwintering shrimp Crangon crangon to the overwintering fish. Nevertheless, manipulative field experiments showed no significant impacts of the most abundant overwintering fish Pomatoschistus microps on prey community densities, despite an overall individual ingestion rate of $89 \mathrm{~J} \mathrm{day}^{-1}$.

Keywords: Pomatoschistus microps, Pleuronectes platessa, energy flow, predator impacts, Culbin Sands lagoon.

RESUMEN: PAPEL ECOLÓGICO EN LA CADENA TRÓFICA DE LOS PECES QUE PASAN El INVIERNO EN ECOSISTEMA DE LA LAGUNA CULBIN SANDS, NE ESCOCIA: IDENTIFICACIÓN DE LAS PRINCIPALES INTERACCIONES TRÓFICAS Y COMPROBACIÓN DE LOS EFECTOS DEL PEZ Pomatoschistus microps (PALlas) en los InVERTEBRAdos Bentónicos. - Se estudió el ecosistema de la laguna Culbin Sands, NE Escocia, durante un periodo de tres años (1994-1996) con objeto de identificar los principales acoplamientos tróficos desde invertebrados bentónicos a depredadores epibentónicos, y para evaluar el impacto de los peces que pasan el invierno sobre las comunidades de sus presas. Cada 2-4 semanas, la fauna móvil se muestreó para estudiar su dieta. Las principales interacciones tróficas identificadas, entre invertebrados bentóncos y depredadores epibentónicos, fueron de los invertebrados bentónicos a la quisquilla Crangon crangon, y a los peces Pomatoschistus microps y Pleuronectes plates$\mathrm{sa}$. El flujo energético desde los invertebrados bentónicos a los peces que pasan el invierno se estimó en $133 \mathrm{~kJ} \mathrm{~m}^{-2} \mathrm{año}^{-1}$. También se observó un flujo de $10 \mathrm{~kJ} \mathrm{~m}^{-2}$ año $^{-1}$ desde los estadios de huevos y larvas de la quisquilla Crangon crangon a los peces que pasan el invierno. No obstante, experimentos de campo manipulativos no mostraron impactos significativos del pez más abundante entre los que pasan el invierno, Pomatoschistus microps, sobre las densidades de las comunidades de presas, a pesar de observarse una tasa global de ingestión individual de $89 \mathrm{~J} \mathrm{día}^{-1}$.

Palabras clave: Pomatoschistus microps, Pleuronectes platessa, flujo energético, impactos de depredadores, laguna de Culbin Sands. 


\section{INTRODUCTION}

Trophic links between community components within coastal systems have been described in detail by many authors (e.g. Raffaelli et al., 2002), with both epibenthic predators and shorebirds being considered important predators of invertebrate organisms. Coastal areas are known to be important nursery grounds for epibenthic fauna but the effects of overwintering species, especially fish, may be significant for their invertebrate prey communities. In general, benthic invertebrate macroinfauna comprise $70 \%$ in volume of the total amount eaten by epibenthic predators. The remaining 30\% are composed of meiofauna $(10 \%)$, other epibenthic fauna (10\%), and "detritus" or "unidentified organic matter" (10\%) (Pihl, 1985). Of the meiofauna, harpacticoids and ostracods are frequently eaten by smaller predators such as the sea scorpions Myoxocephalus scorpius, the pipefish Nerophis lumbriciformis, and the sticklebacks Gasterosteus aculeatus and Spinachia spinachia. Larger fish prefer bivalves (especially siphons), polychaetes and crustaceans such as the amphipods Bathyporeia pilosa and Corophium spp.

In the shallow waters and tidal flats of the North Sea, the brown shrimps Crangon crangon, gobies Pomatoschistus spp. and flatfish (e.g. plaice Peuronectes platessa) are among the most important epibenthic predators (e.g. Gysels et al., 2004). According to Evans (1983), in the Gullmar Fjord, Sweden, production values of Crangon crangon range from 0.6 to $2.4 \mathrm{~g} \mathrm{DW}$ (dry weight) $\mathrm{m}^{-2} \mathrm{yr}^{-1}$, with two main spawning periods (one in April-May and one in October). Gobies Pomatoschistus spp. and the plaice Pleuronectes platessa also spawn in summer and production ranges from 0.1 to $0.2 \mathrm{~g}$ $\mathrm{DW} \mathrm{m} \mathrm{yr}^{-2}$ and from 0.2 to $0.3 \mathrm{~g} \mathrm{DW} \mathrm{m}^{-2} \mathrm{yr}^{-1}$, respectively. Many species move back out to the sea in autumn and return every summer in the breeding season, but the overwintering fish that remain may play an important role in the ecology of the system.

A study carried out in the shallow waters of Sweden has shown annual production values of up to $6 \mathrm{~g}$ AFDW(ash free dry weight) $\mathrm{m}^{-2} \mathrm{yr}^{-1}$ for the most common epibenthic fauna combined, which included the shrimp Crangon crangon, the crab Carcinus maenas, and the fish Pomatoschistus minutus and Pleuronectes platessa, and accounted for up to 100 ind. $\mathrm{m}^{-2}$ for these species combined. These predators consumed up to $98 \%$ of the annual pro- duction of the amphipod Corophium volutator, $92 \%$ of the cockle Cerastoderma edule, and $62 \%$ of the clam Mya arenaria (Pihl, 1985). In the Ythan estuary, NE Scotland, densities of these predators combined are $>100$ ind. $\mathrm{m}^{-2}$ (Raffaelli et al., 1989), with fish taking $54 \%$ of the deposit-feeder production (Baird and Milne, 1981), which is higher than has been recorded in many other aquatic ecosystems. According to Evans (1983), on the Swedish west coast in summer, $60-80 \%$ of the annual benthic invertebrate production in shallow waters is consumed by epibenthic carnivores. On the other hand, $60-80 \%$ of the annual production of shrimps in shallow waters may be cropped by other small-sized epibenthic predators, providing a negative feedback which tends to stabilise the system. These authors and Evans (1985) also showed that in the Wadden Sea, $20-35 \%$ of the benthic invertebrate production may be ingested by epibenthic predators. Nevertheless, Evans (1985) considered that the overall effect of predators was not very important, since $70 \%$ of the annual predation impact occurred between May and August, when fish and shrimps are closer inshore and the small macrofauna are at the peak of production, so effects on community organisation may not be great.

In the present study, the epibenthic fauna communities at Culbin Sands lagoon, Moray Firth, NE Scotland, were studied during the period 1994-1996. The overwintering species were identified and the energy flow from benthic invertebrates to these predators was estimated. Finally, manipulative field experiments were conducted to investigate the predation effects of the overwintering fish Pomatoschistus microps on benthic invertebrate macrofauna.

\section{METHODS}

\section{The study area: Culbin Sands lagoon}

Culbin Sands area (including a forest of 28 ha, and a bared sand dune enclosing a lagoon with 1.5 ha of intertidal flats) is a protected area classified as a Special Site of Scientific Interest since July 1973. The lagoon has a macro-tidal regime with a permanently submersed gully with maximum depth of 2.5 $\mathrm{m}$ at high tide. Closer to the mouth of the main gully, the sediment is coarser and poorer in silt content (Hanssen, 1993). The area has been known as a 


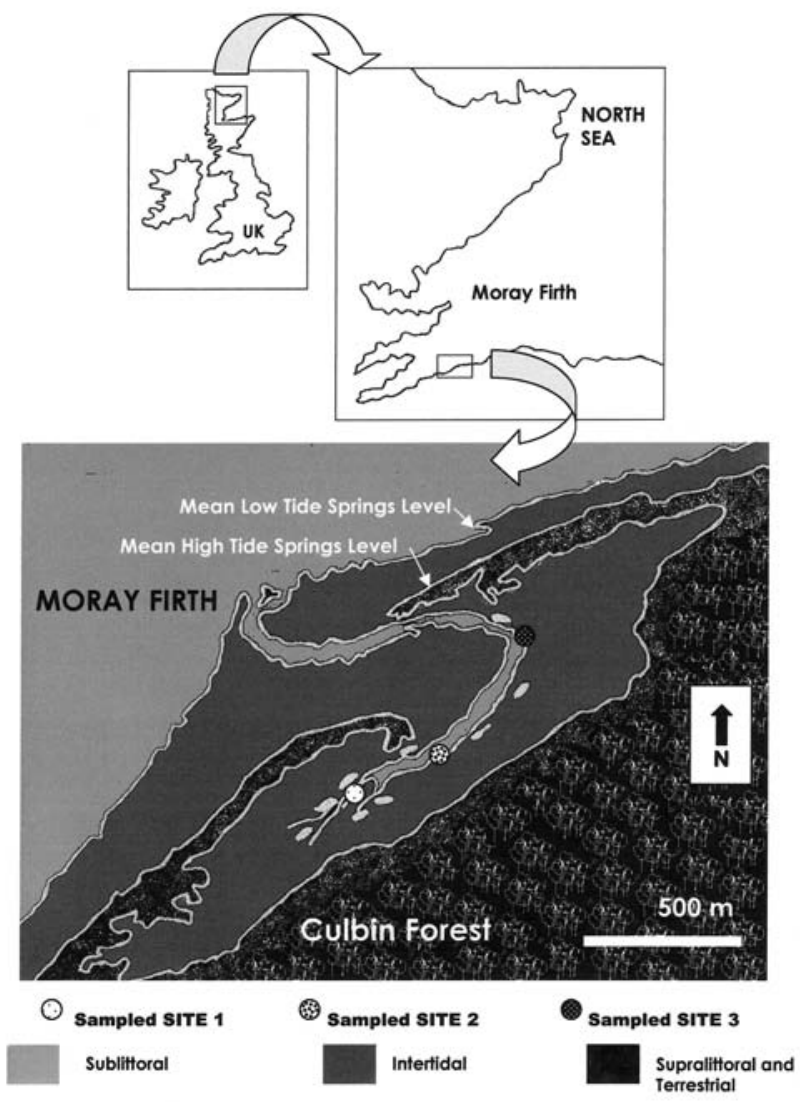

FIG. 1. - Culbin Sands in the southern part of the Moray Firth, NE Scotland, with indication of sampled sites for epibenthic fauna. Manipulative field experiments were carried out at site 1. Light patches on the tidal flat near the main gull represent mussel beds.

nursery for fish species of commercial value (Hopkins, 1986).

\section{Overwintering epibenthic species and their diets}

Epibenthic fauna was sampled at three sites in the Culbin Sands lagoon every 2-4 weeks during the period 1994-1996. The sites did not differ greatly in terms of sediment characteristics (median particle sizes of up to $120 \mu \mathrm{m}$ for Sites 1 and 3 and 130-140 $\mu \mathrm{m}$ for Site 2, and silt contents of 0-5\% for all three sites; Mendonça, 1997), but because differences in the hydrodynamic characteristics of the sites could impact both benthic and epibenthic communities, they were selected according to distance from the bar: Site 1 was in sheltered areas west of the bar, Site 2 closer to the bar, and Site 3 in sheltered areas east of the bar but closer to the mouth of the gully than Site 1 (Fig. 1).

Samples were collected at low tide, when predators have full guts from feeding on the previous high tide (e.g. Healy, 1972), using push-nets of $1 \mathrm{~mm}$ mesh pushed by hand along a $50 \mathrm{~m}$ long transect at depths of $0.5-1 \mathrm{~m}$ in the main gully. All fish caught were measured (from snout to tail end) and wet weighed. Samples were preserved in formaldehyde $(10 \%)$ at the sampling site, in order to stop digestion of prey to study diets. All epibenthic fauna was identified according to Hayward and Ryland (1990). Gut contents were examined under a binocular microscope to identify prey items in stomachs (to the species or nearest taxon), which were counted, and the relative volume of prey in stomachs was recorded. There are several ways to test the relative volume, one of which is using a test-tube with water. Prey numbers provided information on prey frequency of occurrence, FO (Dinnen, 1951), and volumetric composition, VC (Larimore, 1957), in predator diets as follows: $\mathrm{FO}=$ (no. of stomachs with prey item $i$ / total no. of stomachs) $\times 100$; and $\mathrm{VC}=$ (volume of prey item $i$ / Total volume in the stomach) $\times 100$.

Mean percentage by volume of prey items for overwintering epibenthic predators (the brown shrimp Crangon crangon, the common goby Pomatoschistus microps and the plaice Pleuronectes platessa) by predator size class were compared by multivariate cluster analysis, using weighted data entries (KCS, 2001). The sample size was 10 individuals per predator species and per size category, pooled over all sites and months, as there were no significant differences in diets over time (months) and space (sites) (two-way ANOVA; P>0.05 in all cases; Sokal and Rohlf, 1995). Ingested biomass by prey item provided information for consumption estimates of overwintering species, assuming that these predators feed on each tide (Coull, 1990). The biomass of material consumed was converted into Joules using conversion factors (Table 1). Food consumption for the overwintering epibenthic predators was also estimated as a percentage of body weight.

\section{Manipulative experiments to test impacts of overwintering fish on benthic invertebrates}

To test effects of overwintering fish on their prey communities, two caging experiments were set up in an area where the sediment was more stable and currents less strong, in order to minimise hydrodynamic artefacts and dislodgement of the cages (Fig. 1). These conditions are nevertheless representative of the situation inside the lagoon, and both experiments were conducted in the same area. One experiment 
TABLE 1. - Conversion factors for deriving AFDW (ash free dry wieght) from DW (dry wieght), and energy content $\left(\mathrm{J} \mathrm{mg}^{-1}\right) \mathrm{in} \mathrm{prey.} \mathrm{N/A} \mathrm{=}$ not applicable; $1 \mathrm{~J}=0.239 \mathrm{cal} ; 1 \mathrm{cal}=4.187 \mathrm{~J} ; 12 \mathrm{kcal}=1 \mathrm{~g} \mathrm{C}$ (McNeill and Lawton, 1970).

\begin{tabular}{|c|c|c|c|}
\hline Taxa & Size class $(\mu \mathrm{m})$ & $\begin{array}{l}\text { Conversion factor } \\
\text { From DW to AFDW } \\
\text { (Rumhor } \text { et al., 1987) }\end{array}$ & $\begin{array}{l}\text { Conversion factor from weight to energy } \\
\text { Energy content } \mathrm{J} \mathrm{mg}^{-1} \text { (weight type; Reference) }\end{array}$ \\
\hline Meiofauna & $<500$ & 0.70 & 23.40 (DW; Ankar and Elmgreen, 1976) \\
\hline Nemerteans & $<1000$ & 0.70 & 23.40 (DW; Ankar and Elmgreen, 1976) \\
\hline Nematodes & $\begin{array}{l}<1000 \\
>1000\end{array}$ & $\begin{array}{l}0.70 \\
0.30\end{array}$ & $\begin{array}{l}23.40 \text { (DW; Ankar and Elmgreen, 1976) } \\
23.09 \text { (AFDW; Brey et al., 1988) }\end{array}$ \\
\hline Annelids & $\begin{array}{l}<1000 \\
>1000\end{array}$ & $\begin{array}{l}0.70 \\
0.30\end{array}$ & $\begin{array}{l}\text { Oligochaetes: } 22.36 \text { (DW; Brey et al., 1988) } \\
\text { Polychaetes: } 23.33 \text { (AFDW; Brey et al., 1988) }\end{array}$ \\
\hline $\begin{array}{l}\text { Arthropods/Crustaceans } \\
\text { Calanoid Copepods } \\
\text { Crangon crangon eggs } \\
\text { Crangon crangon }\end{array}$ & $\begin{array}{l}<1000 \\
>1000 \\
\text { N/A } \\
\text { N/A } \\
\text { N/A }\end{array}$ & $\begin{array}{l}0.70 \\
0.30 \\
0.70 \\
0.70 \\
0.30\end{array}$ & $\begin{array}{l}22.40 \text { (AFDW; Brey et al., 1988) } \\
22.40 \text { (AFDW; Brey et al., 1988) } \\
24.3 \text { (Dw; Comita and Schindler, 1963) } \\
25.1 \text { (DW; Edwards, 1978) } \\
\text { 17.6 (DW; Evans, 1983) }\end{array}$ \\
\hline Arthropods/Insects & $\begin{array}{l}<1000 \\
>1000\end{array}$ & $\begin{array}{l}0.70 \\
0.30\end{array}$ & $\begin{array}{l}\text { Chironomids: } 23.81 \text { (AFDW; Brey et al., 1988) } \\
\text { Chironomids: } 23.81 \text { (AFDW; Brey et al., 1988) }\end{array}$ \\
\hline Molluscs/Bivalves & $\begin{array}{l}<1000 \\
>1000\end{array}$ & $\begin{array}{l}0.15 \\
0.10\end{array}$ & $\begin{array}{l}22.79 \text { (AFDW; Brey et al., 1988) } \\
22.79 \text { (AFDW; Brey et al., 1988) }\end{array}$ \\
\hline Pomatoschistus spp. eggs & $\mathrm{N} / \mathrm{A}$ & 0.70 & 25.1 (DW; Healy, 1972) \\
\hline
\end{tabular}

ran from October to December 1995 (autumn-winter season), using enclosures of the overwintering fish Pomatoschistus microps (all other epibenthic predators such as shrimps, crabs, and other fish species were not present in the cages), and another set of experiments ran from December 1995 to April 1996 (winter-spring season) using exclosures for all predators. Each cage was $1 \mathrm{~m}^{2}$ in area and $50 \mathrm{~cm}$ high (15 cm into the sediment to anchor the cage), and was covered by a $2 \mathrm{~mm}$ mesh net around a metal frame. A black plastic wall $10 \mathrm{~cm}$ high was fixed around the base of the cage to retain seawater during low tide. In the predator enclosures experiment, four cages containing the goby Pomatoschistus microps at typical densities for Culbin Sands (i.e. 10 ind. cage $^{-1}$; mean $=41.7 \mathrm{~mm}$, from snout to tail, $\mathrm{SE}=$ 0.39 , range 39.6 to $43.1 \mathrm{~mm}$ ), and four cages without predators (exclosures or caged controls) were placed randomly over the area. After seven weeks (sufficiently long to reveal any impact of predators on prey densities and community structure, but not so long that enclosed predators could die; Reise, 1985), fish were collected and preserved at the site in folmaldehyde (4\%) to stop digestion. The mean percentage by volume of each prey item in stomachs of caged predators was compared among caged, and between caged and uncaged areas $(\mathrm{N}=10$ individuals/month; from October to December) by one-way
ANOVA after arc-sin transformation, as it ensured normality. A similar experiment of four cages (excluding all predators) was set up from December to April.

At the end of each caging experiment, six corer samples $($ diameter $=11 \mathrm{~cm} ; 15 \mathrm{~cm}$ into the sediment) were collected from each cage (enclosures; and exclosures or caged controls) and six corer samples were collected randomly from the surrounding uncaged areas (uncaged controls) in order to investigate effects on prey densities. Samples were sieved through $500 \mu \mathrm{m}$ mesh in autumn-winter and through $1 \mathrm{~mm}$ mesh in winter-spring, as larger predators were present from spring. ANOVA was used to compare invertebrate densities in sediments within and between treatments for each season. Given the number of tests conducted, Sequential Bonferroni Tests with $\alpha=0.05$ were carried out to find the critical $\mathrm{P}$ (probability) level of significance (Sokal and Rohlf, 1995). Tukey's pairwise comparisons were conducted when P was significant. Data on molluscs were also analysed by size class to investigate the size of prey missing from uncaged areas. Relative frequencies of molluscs by size class were compared between caged and uncaged samples by ANOVA after arc-sin transformation as it ensured normality.

Another set of three samples per cage and three from uncaged areas was collected in both sets of 
experiments to investigate silt content. For silt content analysis, samples were dried to constant weight $\left(70^{\circ} \mathrm{C}, 24 \mathrm{~h}\right.$; in incinerator), wet sieved through a 63 $\mu \mathrm{m}$ mesh, and dried again to constant weight to provide the percentage of silt (Holme and McIntyre, 1984). Percentages of silt content in the sediment between the treatments were compared by ANOVA (first set of experiments) and U-TEST (second set of experiments).

To avoid potential problems of pseudoreplication, the data from all samples from the same cage (both for invertebrate densities or silt content) were pooled to provide a single value for each cage.

\section{RESULTS}

\section{Overwintering epibenthic species and their diets}

The most abundant epibenthic species at Culbin Sands lagoon were the brown shrimp Crangon crangon (10-100 ind. $\mathrm{m}^{-2}$ ), the common goby Pomatsochistus microps (1-10 ind $\left.\mathrm{m}^{-2}\right)$, and the plaice Pleuronectes platessa (1-10 ind. $\left.\mathrm{m}^{-2}\right)$, although individuals of larger sizes were more commonly observed in summer (Fig. 2). These were also the identified overwintering species; others were only recorded during summer months at densities of 0-1 ind. $\mathrm{m}^{-2}$ (Table 2).

Analyses of stomach contents showed that the overwintering fish Pomatoschistus microps required daily about $3 \%$ of their own body weight, whilst
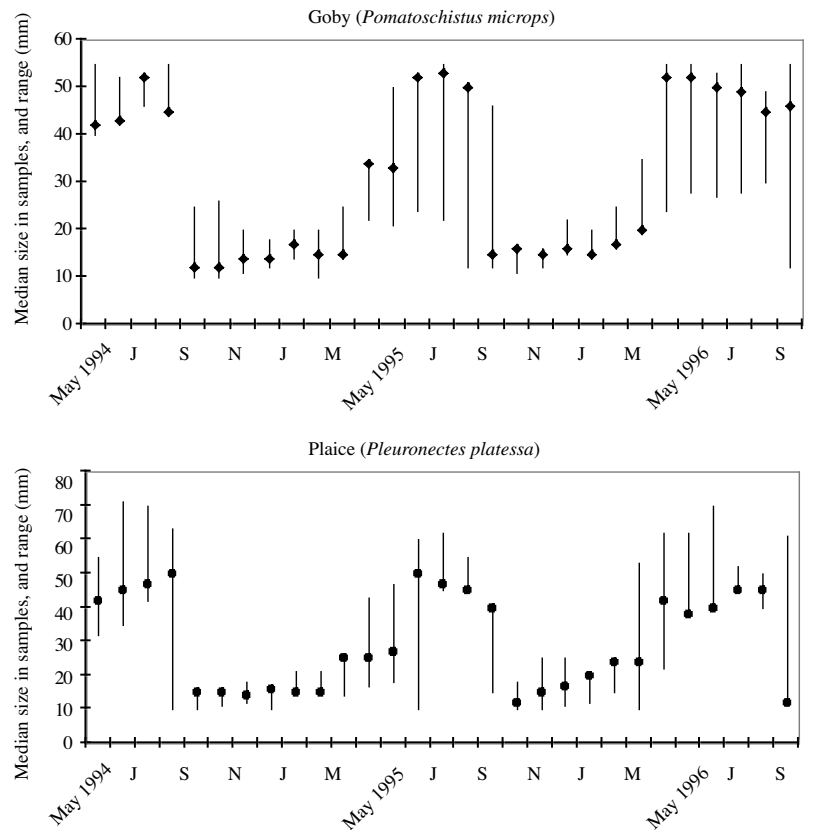

FIG. 2. - Median size of overwintering fish (the common goby Pomatoschistus microps and the plaice Pleuronectes platessa) in Culbin Sands lagoon, NE Scotland, during the period 1994-1996.

overwintering Pleuronectes platessa required daily about $2.5 \%$ of their own body weight. In terms of volume in stomach contents, Bathyporeia pilosa was the most important prey for shrimps and gobies, although gobies also frequently ingested copepods, and plaice ingested preferably harpacticoids and bivalve siphons (Table 3). In terms of energy, most flowed from polychaetes and bivalves to both overwintering fish species, and there was an overall individual ingestion rate of $89 \mathrm{~J}^{\text {day }^{-1}}$ for gobies.

TABLE 2. - Abundance of epibenthic fauna recorded in sampling push-nets at Culbin Sands lagoon, NE Scotland, during the period 19941996, and recorded site of occurrence.

\begin{tabular}{|c|c|c|c|c|}
\hline Taxa & & & Abundance index in & Site of \\
\hline Shrimps & $\begin{array}{l}\text { Brown shrimp } \\
\text { Mysids }\end{array}$ & $\begin{array}{l}\text { Crangon crangon } \\
\text { Praunus flexuosus }\end{array}$ & $\begin{array}{c}10-100 \\
0-1\end{array}$ & $\begin{array}{c}1,2,3 \\
1\end{array}$ \\
\hline Crabs & Shore crab & Carcinus maenas & $0-1$ & 1,3 \\
\hline Starfish & & Asterias rubens & $0-1$ & 1 \\
\hline Fish & $\begin{array}{l}\text { Sandeel } \\
\text { Sandeel } \\
\text { 3-spined Stickleback } \\
\text { 15-spined Stickleback } \\
\text { Sea scorpion } \\
\text { Pipefish } \\
\text { Common goby } \\
\text { Sand goby } \\
\text { Flounder } \\
\text { Plaice }\end{array}$ & $\begin{array}{l}\text { Ammodytes tobianus } \\
\text { Ammodytes sp. } \\
\text { Gasterosteus aculeatus } \\
\text { Spinachia spinachia } \\
\text { Myoxocephalus scorpius } \\
\text { Nerophis lumbriciformis } \\
\text { Pomatoschistus microps } \\
\text { Pomatoschistus minutus } \\
\text { Platichthys flesus } \\
\text { Pleuronectes platessa }\end{array}$ & $\begin{array}{l}0-1 \\
0-1 \\
0-1 \\
0-1 \\
0-1 \\
0-1 \\
1-10 \\
0-1 \\
0-1 \\
1-10\end{array}$ & $\begin{array}{c}1,2 \\
1,2 \\
1 \\
1 \\
1 \\
1 \\
1,2,3 \\
1,2,3 \\
2 \\
2,3\end{array}$ \\
\hline
\end{tabular}


TABLE 3. - Frequency of occurrence (FO) and volumetric composition (VC) of prey in stomachs of most abundant epibenthic predators overwintering at Culbin Sands lagoon, NE Scotland (samples were polled over all sites and months; $\mathrm{N}=30$ ind. per month per predator species, all predators $>20 \mathrm{~mm})(\mathrm{WW}=$ wet weight; $\mathrm{N} / \mathrm{A}=$ not applicable $)$.

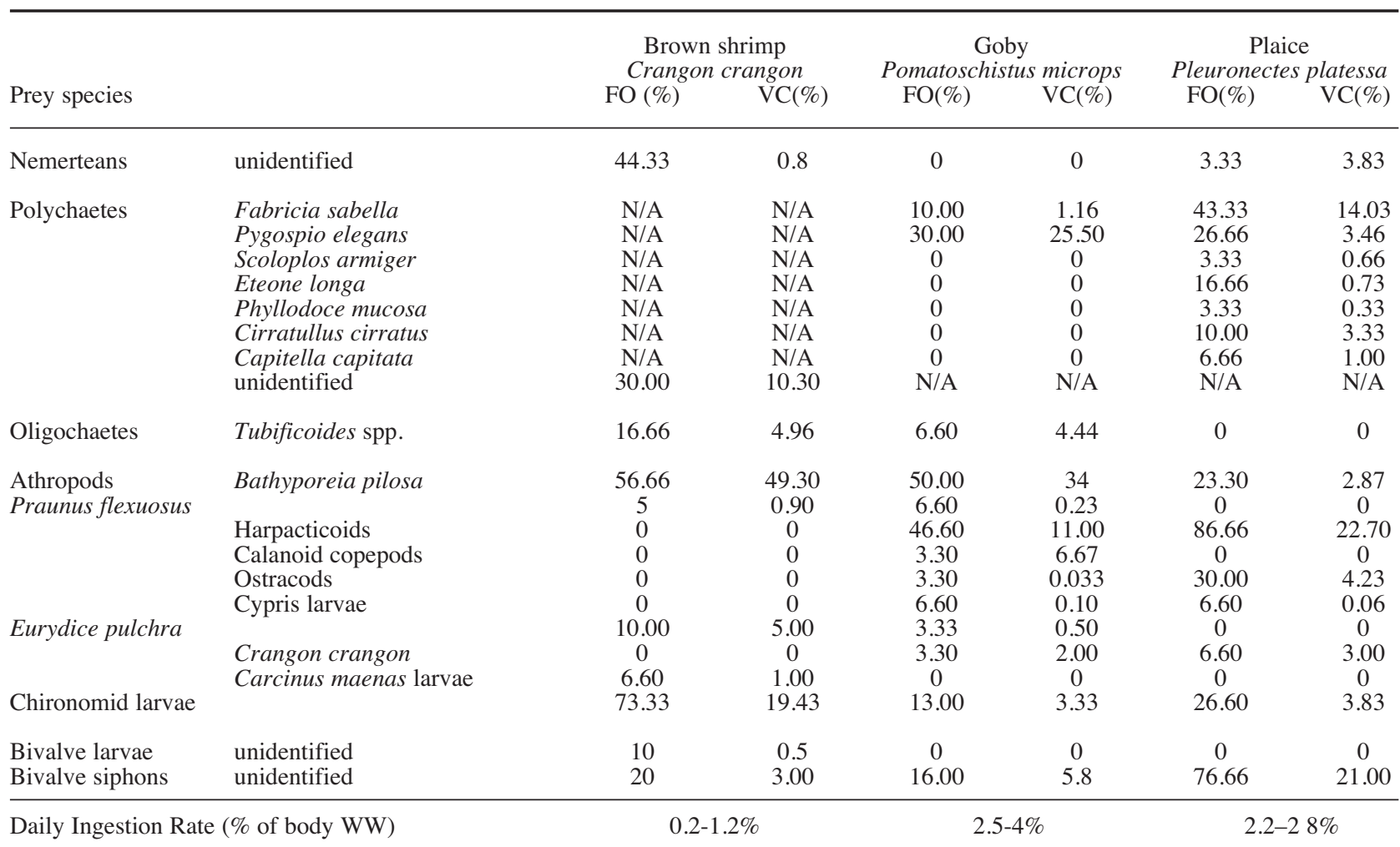

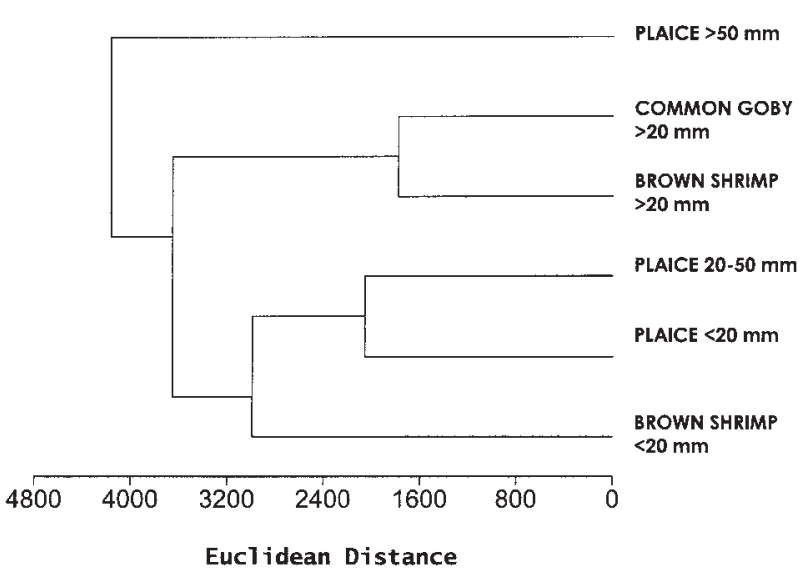

FIG. 3. - Cluster analyses comparing diets of epibenthic fauna at Culbin Sands lagoon, NE Scotland, during the period 1994-1996.

Comparisons of diets of the overwintering predators using multivariate analysis showed that whichever the species, smaller individuals had similar diets among themselves (even from different species), and distinct from larger individuals (both of the same and of different species) (Fig. 3).

Based on daily ingestion rates and extrapolating to the whole Culbin Sands lagoon, overwintering epibenthic fauna consumed annually $283 \mathrm{~kJ} \mathrm{~m}^{-2}$

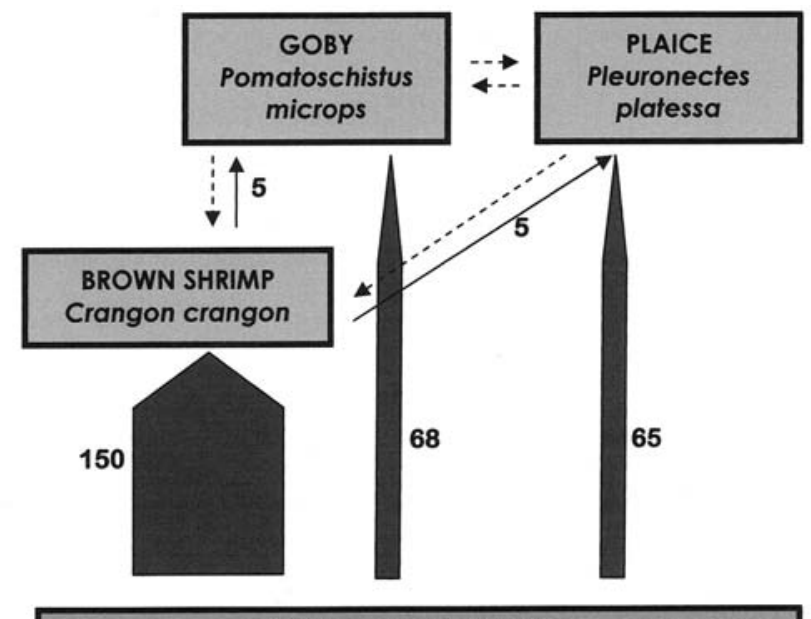

BENTHIC INVERTEBRATES

\section{$\mathrm{kJ} \mathrm{m}^{-2} \mathrm{yr}^{-1}$}

FIG. 4. - Major energy flow from benthic invertebrates to epibenthic predators (dashed arrows represent minor energy flow from eggs and larval stages).

$\mathrm{yr}^{-1}$, of which $133 \mathrm{~kJ} \mathrm{~m}^{-2} \mathrm{yr}^{-1}$ was by fish (gobies and plaice) and $150 \mathrm{~kJ} \mathrm{~m}^{-2} \mathrm{yr}^{-1}$ by shrimps. Also, a flow of $10 \mathrm{~kJ} \mathrm{~m}^{-2} \mathrm{yr}^{-1}$ was estimated from eggs and larval stages of the shrimp Crangon crangon to fish (Fig. 4). 

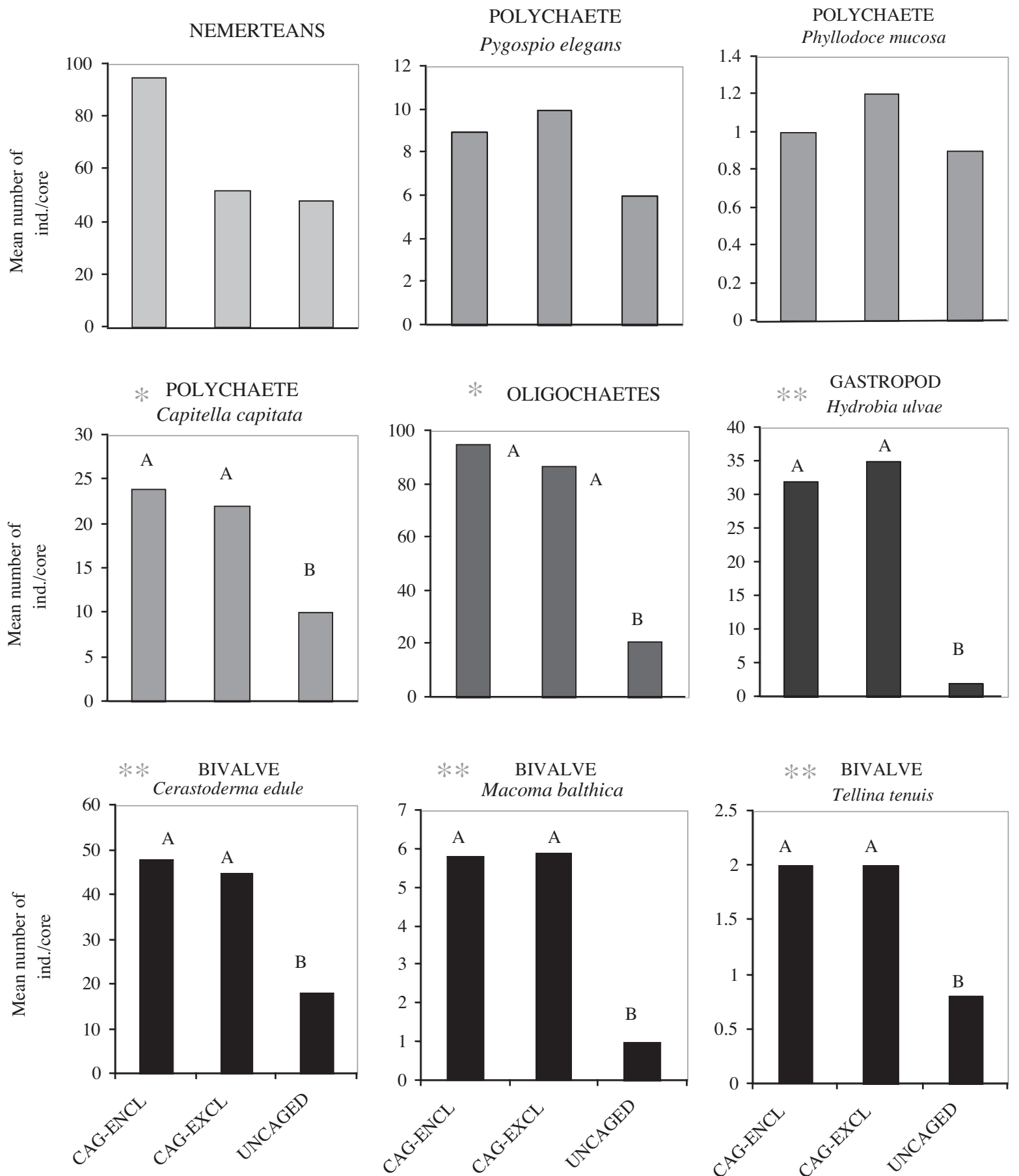

FIG. 5. - Testing effects of overwintering fish Pomatoschistus microps on benthic invertebrate density in autumn-winter: absolute frequency of most common benthic invertebrates in caged and uncaged areas (A and B are homogenous subgroups after Tukey's pairwise comparisons when $\mathrm{P}$ was significant; * $\mathrm{P}$ just above level of significance; ** P level significant; ANOVA; Bonferroni).

\section{Manipulative experiments to test impacts of overwintering fish on benthic invertebrates}

Manipulative field experiments showed, nevertheless, no significant impacts of overwintering fish on their prey populations. Results showed no significant differences between enclosures of predators (caged areas with predators) and exclosures of predators (caged areas without predators) either in autumn-winter when effects of gobies alone were tested (Fig. 5) or in winter-spring when combined effects of all predators were tested (Fig. 6). However, there was some degree of depletion from uncaged areas of the polychaetes Capitella capitata 
and oligochaetes (mostly Tubificoides benedini) in autumn winter (Fig. 5), and of the polychaetes Pygospio elegans in winter-spring (Fig. 6). This may have been due to the predation pressure by other predators such as birds or due to the combined predation pressure by all species of overwintering fish, shrimp and birds altogether.

There were also significant differences between caged (enclosures and exclosures) and uncaged areas in densities of the gastropods Hydrobia ulvae and the bivalves Cerastoderma edule, Macoma balthica and Tellina tenuis, with higher densities in caged areas where gobies were in higher concentrations. These differences were not likely to be due to siltation (ANOVA for October-December experiment; T/UTEST for December-April experiment: $\mathrm{P}>0.05$ in all cases). Also, the lower molluscan densities in uncaged areas could not have been due to the action
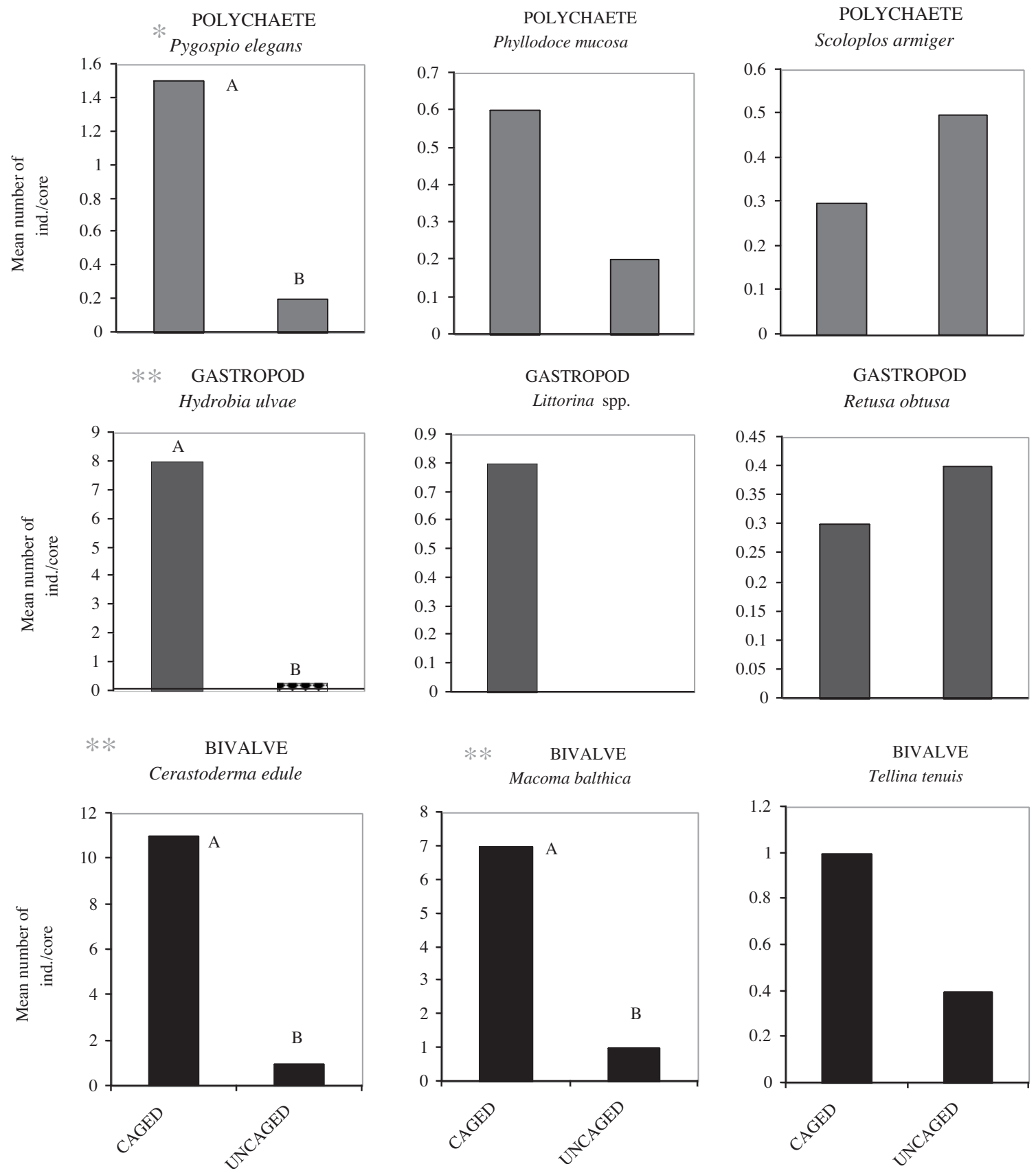

FIG. 6. - Testing effects of overwintering fish Pomatoschistus microps on benthic invertebrate density in winter-spring: absolute frequency of most common benthic invertebrates in caged and uncaged areas (A and B are homogenous subgroups after Tukey's pairwise comparisons when P was significant; * P just above level of significance; ** P level significant; ANOVA; Bonferroni). 

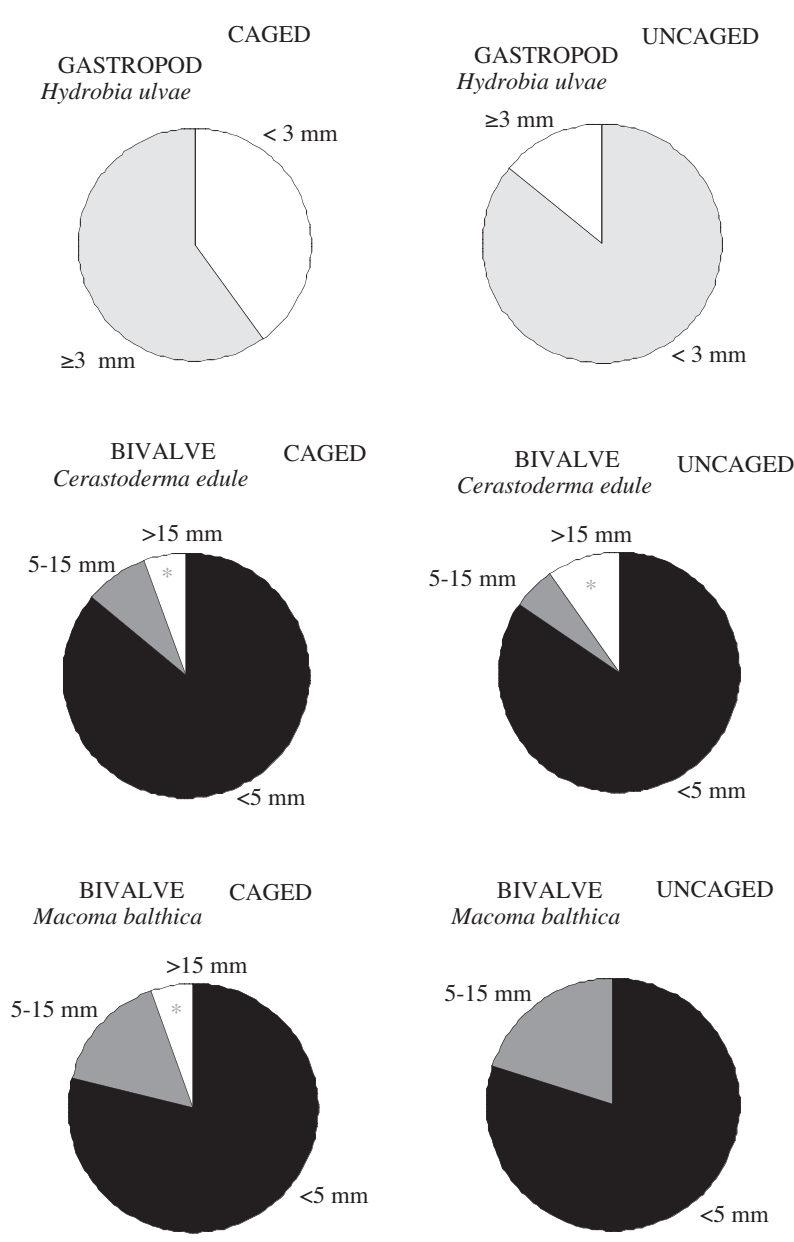

FIG. 7. - Relative abundance of larger-sized molluscs between caged and uncaged areas during the autumn-winter season $(* \mathrm{P}$ just above level of significance; ANOVA, Bonferroni).

of epibenthic predators as only sizes too large for these predators were less abundant (Figs. 7-8).

Survival of fish in cages, over the 7 weeks could not be estimated as only half of the individuals were re-captured. Although there was no way for them to escape, the remaining ones were not found either dead or alive, suggesting that they may have been in chambers in the sediment. Analyses of the available fish stomach contents showed no significant differences in diets between the caged and uncaged fish (ANOVA: $\mathrm{P}>0.05$ in all cases).

\section{DISCUSSION}

\section{Overwintering epibenthic fauna and their diets}

In the present study, epibenthic species occurred most frequently near musselbeds (site 1), only
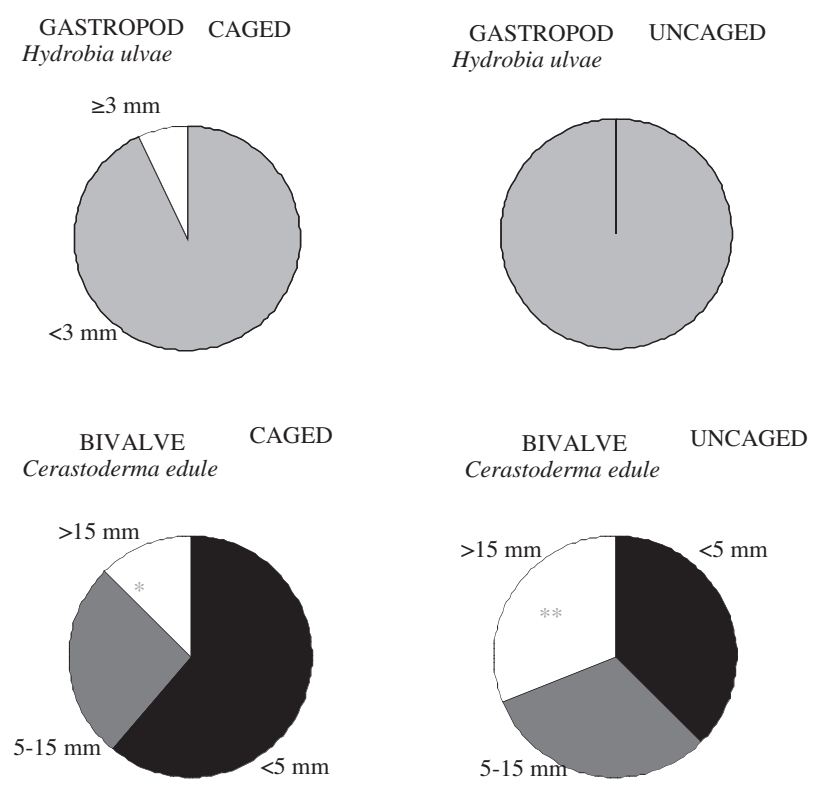

Cerastoderma edule
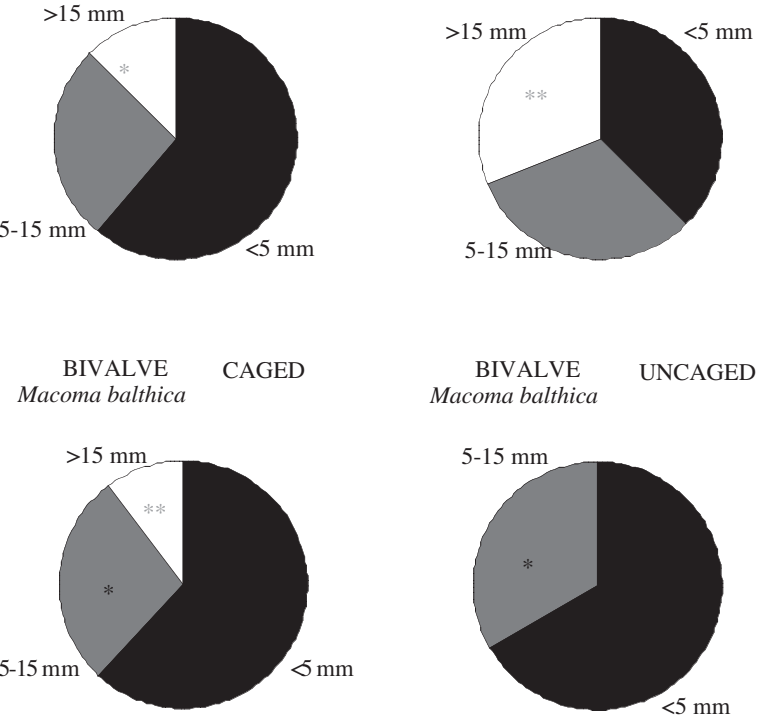

FIG. 8. - Relative abundance of larger-sized molluscs between caged and uncaged areas during winter-spring season (* P just above level of significance; ** $\mathrm{P}$ level significant; ANOVA, Bonferroni).

reflecting higher invertebrate densities at these sites (Mendonça, 1997). This result is in line with studies conducted by Gunther (1996) in musselbeds of Mytilus sp. Additionally, empty bivalve shells provide ideal sites for nests to be built by gobies (and guarded by males; e.g. Klug et al., 2005), and several male Pomatoschistus microps were observed in the present study having nuptial coloration.

Though they were present all year round, both the gobies Pomatoschistus microps and the plaice Pleuronectes platessa were more abundant in summer, reflecting their life cycles. According to studies carried out by Healy (1969) in the North Sea, gobies return from the open sea to colonise shallower waters in spring, as June is the middle of the breeding season, and flatfish come back around the same time and in late autumn (Summers, 1974). The first appearance of the plaice Pleuronectes platessa and the flounder Platichthys flesus usually occurs with 
the peak biomass of brown shrimps Crangon crangon, and at similar depths (Modin and Pihl, 1996). Green (1968) remarked that plaice and flounder do not usually occur together, because flounders tolerate lower salinity than plaice. This probably explains why plaice were more abundant at Culbin Sands, where there was little fresh water. Doornbos and Twisk (1987) also note that Pomatoschistus minutus may remain longer in shallower waters and may even show some degree of migration inshore in later autumn. In addition to these seasonal patterns, over a time scale of days or weeks fish can move in response to changes in food density (Boddeke, 1996). Crangon crangon shrimp concentrations and distribution may also depend on the predation pressure, because they are prey for many fish species although they are also predators of eggs and larval stages of fish (e.g. Gibson et al., 1995), as also observed in the present study. Pleuronectes platessa was also more abundant near Culbin Bar (site 2) than at any other site, probably because this fish species requires open flat bottoms composed of either coarse sand or mud (Ansell and Gibson, 1990), but near musselbeds there were many bivalve shells present, providing better habitats for gobies than for flatfish and also refuge from predators for larval and juvenile stages (e.g. Fokestad, 2005).

Daily values of percentage of body weight ingested by both Pomatoschistus microps and Pleuronectes platessa estimated in the present study were within ranges also found by Evans (1983) for the Gullmar Fjord in Sweden. However, the energy flow from benthic invertebrates to these fish species at Culbin Sands $\left(68 \mathrm{~kJ} \mathrm{~m}^{-2} \mathrm{yr}^{-1}\right.$ for gobies, and $65 \mathrm{~kJ}$ $\mathrm{m}^{-2} \mathrm{yr}^{-1}$ for plaice) was higher than that estimated by Evans (1983) in Sweden (15 kJ m-2 $\mathrm{yr}^{-1}$ for gobies, and $20 \mathrm{~kJ} \mathrm{~m}^{-2} \mathrm{yr}^{-1}$ for plaice). These differences could be because in the present study predators were collected during low tide when they are more concentrated, and in this case densities could have been overestimated. Nevertheless, numbers recorded at Culbin Sands appear similar to those found in other areas of Britain and the North Sea for both gobies and plaice (Pihl and Rosenberg, 1982), so it is unlikely that they were overestimated. Moreover, we used lower values of the range of abundance for estimates of consumption rates.

In the present study, epibenthic predators were caught at low tide and most feed mainly during rising tide (e.g. Summers, 1974). Therefore, some of the food may have already been digested at the time of sampling and the harder, less digestible prey items may have been over-represented in the guts. However, this is not thought to be a major problem because some of the predators caught had empty or not yet full stomachs, suggesting that they also feed on the ebb tide. Similar results were obtained by Gibson and Hesthagen (1981). Nevertheless, del Norte Campos and Temming (1994) argue that Crangon usually eat at dawn and very little at noon and gobies eat at daylight, dusk and sunrise, consuming up to $3 \%$ of their body weight daily. Nevertheless, the over-representation of certain prey could have impacted estimates of energy flow.

\section{Manipulative experiments to test impacts of overwintering fish on benthic invertebrates}

The occurrence of bivalve recruitment in autumn at Culbin Sands was obvious from the tremendous increase in numbers of small bivalves found in caged areas, although the presence of cages could also have produced exaggerated differences in numbers of small bivalves between caged and uncaged areas, as conditions in caged areas may favour settlement of larvae. However, cage artefacts seem unlikely because there were no significant differences in silt content between caged and uncaged areas. Least likely but also possible, higher numbers of small bivalves as well as of small Hydrobia ulvae in caged areas from October 1995 to December 1995 and from December 1995 to April 1996 may also have been associated with the macroalgal mats growing in caged areas, although they had been cleaned every week. Macroalgae and other biogenic structures seem to promote higher numbers of infaunal species, until a point is reached where weed turns the sediment anoxic and populations start to decline (e.g. Cardoso et al., 2004). Finally, as the proportion of small molluscs (Hydrobia and bivalves) was not significantly different between caged and uncaged areas, the number of small molluscs in caged areas may simply indicate molluscan production when effects of both epibenthic predators and birds are totally removed.

Despite the predation pressure by overwintering fish (the common gobies Pomatoschistus microps) on benthic macrofauna, manipulative field experiments carried out at Culbin Sands showed no significant impacts on prey communities (first set of experiments), even when the predation pressure of all overwintering epibenthic predators was com- 
bined (second set of experiments). These results were in line with those found by other authors using caging experiments to test effects of epibenthic predators (including gobies) on their prey community densities (Henry and Jenkins, 1995).

A lack of significant negative effects of overwintering fish on their prey communities was due to the fact that predators only ingested part of their prey (e.g. cropping on polychaete tails and bivalve siphons), thus permitting their regeneration (e.g. Sandberg et al., 1996), or ingested small nemerteans, bivalve larvae and other prey, which are very abundant and have very high mortality rates anyway (Guillou, 1994).

Therefore, estimates of the impact of predators based only on predator consumption efficiencies (consumption/prey production) or on the energy flow are not always reliable, since predation does not necessarily mean mortality for the prey species.

Finally, the removal of larger size classes from uncaged areas could not have been due to the combined effect of small-mouthed overwintering fish but, as has been further investigated by Mendonça et al. (2007), was due to predation pressure by shorebirds.

\section{ACKNOWLEDGEMENTS}

During this study, the first author was supported by the Ministry of Science, Technology and Higher Education of Portugal (PhD Research Fellowship Reference BD/CIÊNCIA/2593-IG, 25\% co-financed by the European Union Social Fund). We are also grateful for the logistics provided by the University of Aberdeen, and the collaboration of technicians (Mr. Steve Hoskins, Mr. Robert Donaldson, Ms. Sue Way and Mr. Charlie Thomson) and colleagues (Dr. Deborah Cha, Dr. Emillio Abelha, Ms. Huai Chang, and Dr. Stephen Ragnarsson). We also gratefully acknowledge the help provided by the relevant authorities to access the study site: our thanks especially to Mr. David Law of the Scottish Natural Heritage / North East Region, Elgin, UK. Finally, we thank Prof. Robert Gibson for providing expert insights into goby ecology.

\section{REFERENCES}

Ankar, S. and R. Elmgreen. - 1976. The benthic macro- and meiofauna of the Asko-Landsort area (northern Baltic proper). A stratified random sampling survey. Contrib. Asko Lab., 11: 1-115.
Ansell, A.D. and R.N. Gibson. - 1990. Patterns of feeding and movement of juvenile flatfish on an open sandy beach. In: M. Barnes and R.N. Gibson (eds.), Trophic relationships in the marine environment, Proc. 24th Europ. Mar. Biol. Symp., pp. 191-207. Univ. Aberdeen.

Baird, D. and H. Milne. - 1981. Energy flow in the Ythan estuary, Aberdeenshire, Scotland. Estuar. Coast. Shelf Sci., 13: 455-472.

Boddeke, R. - 1996. Changes in the brown shrimp (Crangon crangon L.) population off the Dutch coast in relation to fisheries and phosphate discharge. ICES J. Mar. Sci., 53(6): 995-1002.

Brey, T., H. Rumohr and S. Ankar. - 1988. Energy content of macrobenthic invertebrates: general conversion factors from weight to energy. J. Exp. Mar. Biol. Ecol., 117: 271-278.

Cardoso, P.G., M.A. Pardal, D.G. Raffaelli, A.I. Lillebo, A. Baeta and J.C. Marques. - 2004. Macroinvertebrate response to different species of macroalgal mats and the role of disturbance history. J. Exp. Mar. Biol. Ecol., 302: 233-248.

Comita, G.W. and D.W. Schindler. - 1963. Calorific values of microcrustacea. Science, 140: 1394-1396.

Coull, B.C. - 1990. Are members of the meiofauna food for higher trophic levels? Trans. Am. Microsc. Soc., 109(3): 233-246.

Dinnen, C.F. - 1951. A comparative study of the food habits of Collus bairdii and associated species of Salmonidae. Am. Midl. Nat., 46: 640-645.

Doornbos, G. and F. Twisk. - 1987. Density, growth and annual food consumption of gobiid fish in the saline lake Grevelingen, The Netherlands. Neth. J. Sea Res., 21: 45-74.

Edwards, R.R.C. - 1978. Effects of water-soluble oil fractions on metabolism, growth, and carbon budget of the shrimp Crangon crangon. Mar. Biol., 46: 259-265.

Evans, S. - 1983. Epibenthic communities on shallow soft bottoms in Gullmar Fjord, Sweden. Ph. D. thesis, Univ. Uppsala.

Folkestad, H. - 2005. Stage dependent habitat use under conflicting predation pressure: An experimental test with larval and juvenile two-spotted gobies, Gobiusculus flavescens Fabricius. J. Exp. Mar. Biol. Ecol., 323: 160-171.

Gibson, R.N. and I.H. Hesthagen. - 1981. A comparison of the activity patterns of the sand goby Pomatoschistus minutus (Pallas) from areas of different tidal range. J. Fish Biol., 18: 669-684.

Gibson, R.N., M.C. Yin and L. Robb. - 1995. The behavioural basis of predator-prey size relationships between shrimps (Crangon crangon) and juvenile plaice (Pleuronectes platessa). J. Mar. Biol. Ass. UK, 75(2): 337-349.

Green, J. - 1968. The biology of estuarine animals. Sidgewick and Jackson, London.

Guillou, J. - 1994. Post-larval and juvenile mortality in a population of the edible cockle Cerastoderma edule (L.) from northern Brittany. Neth. J. Sea Res., 33(1): 103-11.

Gunther, C.P. - 1996. Development of small Mytilus beds and its effects on resident intertidal macrofauna. Mar. Ecol., 17(1-3): $117-130$.

Gysels E.S., B. Hellemans, C. Pampoulie and F.A.M. Volckaert. 2004. Phylogeography of the common goby, Pomatoschistus microps, with particular emphasis on the colonization of the Mediterranean and the North Sea. Mol. Ecol., 13: 403-417.

Hayward, P.J. and J.S. Ryland. - 1990. The marine fauna of British isles and Northwest Europe. Vol. I and II. Clarendon Press, Oxford.

Healy, M.C. - 1969. The distribution and abundance of sand gobies Gobius minutus in the Ythan estuary. Ph. D. thesis, Univ. Aberdeen.

Healy, M.C. - 1972. On the population ecology of the common goby in the Ythan estuary. J. Nat. Hist., 6: 133-145.

Henry, B.A. and O.P. Jenkins. - 1995. Impact of predation by the girdled goby Nesogobius sp. 1 on abundances of meiofauna and small macrofauna. J. Exp. Mar. Biol. Ecol., 191(2): 223-238.

Holme, N.A. and A.D. McIntyre. - 1984. Methods for the study of marine benthos. Blackwell, Oxford.

Hopkins, P.J. - 1986. Exploited fish and shellfish species in the Moray Firth. Proc. R. Soc. Edinb., 91B: 57-72

Klug, H., A. Chin and C.M. St Mary. - 2005. The net effects of guarding on egg survivorship in the flagfish Jordanella florida. Anim. Behav., 69: 661-668.

KCS. - 2001. Multivariate statistical package, MVSP. Version 3.1. User's Manual. Kovanch Computing Services, Wales.

Larimore, W.R. - 1957. Ecological life history of the warmouth 
(Centrarchidae). Bull. St. Nat. Hist. Surv. 27: 81-82.

Kuipers, B.R. and R. Dapper. - 1981. Production of Cangron cangron in the tidal zone of the Dutch Wadden Sea. Neth. J. Mar. Res., 15: 33-53.

Lockwood, S.J. - 1980. The daily food intake of 0-group plaice Pleuronectes platessa L. under natural conditions. J. Cons. Int. Explor. Mer, 39: 154-159.

Mendonça, V.M. - 1997. Predator-prey interactions in a sandy shore system in the Moray Firth, NE Scotland. Ph. D. thesis, Univ. Aberdeen.

Mendonça, V.M., D.G. Raffaelli and P.R. Boyle. - 2007. Interactions between shorebirds and benthic invertebrates at Culbin Sands lagoon, NE Scotland: Effects of avian predation on their prey community density and structure. Sci.Mar., 71(3): 579-591.

McNeill, S. and J. H. Lawton. - 1970. Annual production and respiration in animal populations. Nature, 225: 472-474.

Modin, J. and L Pihl. - 1996. Small-scale distribution of juvenile plaice and flounder in relation to predatory shrimp in a shallow Swedish bay. J. Fish Biol., 49(6): 1070-1085.

del Norte-Campos, A.G. and A. Temming. - 1994. Daily activity, feeding and rations in gobies and brown shrimp in the northern Wadden Sea. Mar. Ecol. Prog. Ser., 115: 41-53.

Pihl, L. - 1985. Mobile epibenthic population dynamics, production, food selection and consumption on shallow marine soft bottoms, Western Sweden. Ph. D. thesis, Inst. Mar. Res. Goteborgh.

Raffaelli, D., A. Conacher, H. MacLachlan and C. Emes. - 1989. The role of epibenthic crustacean predators in an estuarine food web. Estuar. Coast. Shelf Sci., 28: 149-60.

Raffaelli, D.G., M. van der Heijden, W. van der Putten, E. Kenedy, J. Koricheva, G. Lacroix, J. Mikola, L. Persson, O. Petchey and D.A. Wardle. - 2002. Multi-trophic processes and ecosystem function. In: M. Loreau, S. Naeem and P. Inchausti (eds.), Biodiversity and Ecosystem Functioning, pp. 147-154. Oxford Univ. Press.

Reise, K. - 1985. Tidal flat ecology - An experimental approach to species interactions. Ecol. Studies 54. Springer Verlag, Berlin.

Sandberg, E., M. Tallqvist and E. Bonsdorff. - 1996. The effects of reduced oxygen content on predation and siphon cropping by the brown shrimp Crangon crangon. Mar. Ecol., 17(1-3): 411-423.

Sokal, R.R. and F.J. Rohlf. - 1984. Biometry. 2nd. W. H. Freeman and Co., London.

Summers, R.W. - 1974. The feeding ecology of the flounder Platichthys flesus (L.) in the Ythan estuary, Aberdeenshire. $\mathrm{Ph}$ D. thesis, Univ. Aberdeen.

Scient. ed.: I. Palomera.

Received November 8, 2006. Accepted July 12, 2007.

Published online October 3, 2007. 